\title{
Evaluating Recommended Literature Texts for Senior Basic Education in Nigeria
}

\author{
Edith Ifeyinwa Obi \& Odochi Silver Akujobi \\ *http://dx.doi.org/10.4314/ujah.v15i2.5
}

\section{Abstract}

The beauty and usefulness of a literary piece lie basically on the author's diction. The expression, 'literary art' stems from the fact that literary artists are able to create interesting works of art by proper manipulation of language(s) that among other things entertain and educate their reading audience. For young minds, literature is not only didactic; it also boosts their language acquisition. In recognition of the crucial roles played by literature, Anambra State Universal Basic Education Board recommended an appreciable number of textbooks for the study of literature in English. These books run from 2010-2011, 2011-2012, 2012-2013 academic sessions. The thrust of this study is to ascertain the grammatical level of the language of some of these texts, particularly the genres of prose and drama. Error analyses of three texts namely: Decree of the gods, Wishful Bliss and That's My Girl randomly selected from basic 7-9 were carried out. Concord incongruity, omission/superfluous use of articles and misuselomission of pronouns were specifically sought for. A simple survey design was adopted for the study and the errors were collated, analyzed and classified based on their types-syntactic, morphological, and concord errors. The study reveals that the texts are replete with concord errors, misuse of articles, omission and improper application of prepositions in structures. The implication of the findings in the teaching and learning of English is discussed and suggestions for improvement made. 
Key words: Literary art(ist), Language acquisition, Grammatical level, Error analysis, Concord incongruity, Articles and Pronouns

\section{Introduction}

The English language plays very important roles in Nigeria. The heterogeneous nature of the country and its consequent multiplicity of languages made the knowledge of English a sine-qua-non for the communal/corporate existence of the citizenry. The language enjoys a pride of place in education, economy, politics, finance, commerce and social life of the country. Eyisi (2) affirms 'that in the school system, success in virtually all subjects is rooted on the extent to which a student has internalized the structure of English and no one in Nigeria can ascend the educational ladder without some degree of proficiency in the language'. To the majority of Nigerians, the yardstick for measuring the degree of one's academic prowess is one's performance in the English language.

One of the broad aims of education as stipulated in the National Policy on Education is:

'The acquisition of appropriate skills and the development of mental, physical and social abilities and competences as equipment for the individual to live and contribute to the development of society'(8).The English language is the pivotal medium through which the skills and competence required for the progress of the country are acquired and harnessed.

In appreciation of the inestimable value of English for the survival of Nigeria in both domestic and international affairs, great efforts have been made by the government and concerned individuals to explore the possible means of promoting acquisition of proficiency in the language. The controversial debate on the fallen standard of education, 
which hinges on the poor performance in English came up shortly after Nigerian independence and has been sustained since then. The clarion call and suggestions for improvement are yet to yield positive results.

Many issues have been highlighted as the factors that militate against the effective teaching and learning of English in Nigeria. Among these are dearth of sufficiently qualified teachers of English, nonchalant attitude of teachers to the teaching of English language, non-availability of teaching aids, and poor reading culture. The immediate result is a gross decline in the quality of English that are learnt in Nigerian Schools. The question therefore is, "where does change probably need to occur in order to bring about the kind of impulses which will support effective acquisition of English as a second language?" (Akwanya, 5-6).

To address the worrisome question, there is a proliferation of textbooks in Nigerian markets, and predominant among these texts are novels, novellas, short stories and drama texts. A good number of these texts are recommended for secondary school students. This is in recognition of the fact that habitual reading is a major key to academic success. Regular interaction with well-written texts is a prerequisite for the acquisition of vocabularies in different fields of human endeavor. It provides a continuous and consistent exposure to the workings of a language; it provides models of performance and transforms one from a good reader to a good writer. The reader is equally exposed to the culture and thought patterns of people from different backgrounds. However, when these texts are replete with grammatical errors, they become fertile grounds for inducing and reinforcing errors. When such errors are fossilized, it becomes difficult to learn the correct forms. It is, therefore, the intention of the present researchers to find out the grammatical level of some of the recommended literature texts 
for Basic 7-9 students and make suggestions for improvement.

\section{Relationship between Language and Literature}

Literature is defined in Oxford Advanced Learner's Dictionaryas 'pieces of writing that are valued as works of art especially novels, plays and poems(869).Language, a special tool for human interaction and communication, is a vital medium of literature. It is language that brings literature into existence. Leech explains that 'everyday language is the starting point for the consideration of the way language is used to convey the mock reality of fiction' (150). Hence, the beauty of literature cannot be recognized beyond the boundary of language.

As an art, literature involves careful planning and execution. A literary artist must be thorough and careful in his approach. The popular definition of poetry by Wordsworth as 'the spontaneous overflow of powerful feelings recollected in tranquility' involves 'successful composition' and the composition of course, involves writing in a language which is a deliberate and painstaking activity' (Akwanya 39-40).

Uzoho explains that 'literature is generally seen as the reservoir of language while language is the vehicle or medium through which the study of literature is made possible' (59). A literary piece rendered in a flawless language whets the appetite of the reader who would definitely ask for more eloquent literary texts. Perhaps the old argument that literature entertains the reader might be true if one considers the pleasurable emotion the language of a literary text arouses in the reader and not by how interesting the content of the story is. This rhymes with the formalist theory that the success of a story or its literariness is achieved by the author's choice of words and his careful, correlative and technical application of these words. 
Every good literature contains imaginative vitality and it sharpens the reader's own imaginative life. This culminates in making the reader a good essayist. 'The reader comes in direct contact with the correct combination of words to form grammatical and acceptable sentences in the language' (Nnamdi Eruchalu 261-262). Gradually, he internalizes the rules that guide the target language. Hence, John maintains that 'any English programme aiming to produce competent English specialist must be characterized by a preponderance of literature courses over language/linguistic courses' (8).

Literature is not only a vehicle of didacticism, it equally encourages readers to acquire good reading habits as well as appreciate the aesthetic value in different forms of writing. Oyetunji quoted in Azikiwe espouses it thus:

The learner develops taste for good literature (i.e. good writing) and dictates for poor writing... He develops fluency

and the ability to read assorted literary

texts which enables him to express ideas and his views effectively in a conversation, and finally with the artistry in different genres, he might develop the interest to write like some of the actors he has read (Azikiwe 2006).

It is an indisputable fact that good reading habit is the only gateway to academic success. A study of WASSCE Chief Examiners' reports of 2009, 2010, 2012, for instance, revealed that students poor performance in literature was contributed by the candidates' shallow and poor answers to questions because of the candidates' limited vocabulary and poor command of the English language; as well as the candidates' refusal to read the selected texts and poems. 
Prose, the most widely read form of literature, offers students a valuable opportunity of putting into practice some of the language techniques learnt in the English language class. Suffice it to say that the best way to teach the meaning of words is contextually. The learner is exposed to the fact that a single word can be used in numerous contexts. This he learns through informal and pleasurable way. Hence literature encourages learner autonomy. Ifechelobi describes learner autonomy 'as a situation in which the learner is totally responsible for all the decision concerned with his (or her) learning and the implementation of those decisions' (59).She further explains that autonomy has been viewed as 'a means to an end of learning a foreign or a second language or as an end itself.' (59) Through autonomous learning of literary texts, the learner acquires the basic language skills.

Drama texts also constitute valuable materials which help learners to acquire the four language skills of listening, speaking, reading and writing. Through role playing, learners are exposed to both formal and informal methods of speech presentation, accompanied by appropriate gestures. Gradually, the learners acquire proficiency and improve on their communicative competence in the target language. They experiment directly with the language and can easily discover and correct their language faults.

Poets use language of grandeur to pass their messages across to the reading audience. They beautify their work with figurative and metaphorical use of language and this projects the entire imagery of the works to the minds to the readers. 'Imagery is the life blood of literature. It helps to create setting, establish a mood or describe sound, smells and sights' (Ezeaku, 229). Poets conjure the mental pictures by using words with greater awareness, greater sensitivity and greater artistry. By reading good poems, the learners' awareness of the language of the poems is intensified. The advanced 
grammatical construction found in poems offers students the advantage of acquiring advanced English vocabularies. The language of poetry contains the necessary ingredients that contribute to the teaching and learning of English as a second language. The poet's construction of works like the use of foreign imagery and symbols helps the students to be acquainted with symbols outside their own environment.

Language and literature are so entwined that one cannot do without the other. They are inseparable complementary sides of the same coin as far as acquisition of proficiency in a language is concerned. In spite of these enormous advantages ascribed to the study of language through literature, the language of an appreciable number of literature textbooks recommended for Nigerian Senior Basic Education students leave much to be desired.

The use of substandard texts for the study of literature in English at the Junior Basic Level of Education in Anambra state is indeed a worrisome development. The aforementioned level of education is the cornerstone on which the higher levels of education are laid. If the study of English at this level is bedeviled with faulty teaching and learning, it becomes a serious academic problem that will be very difficult to solve. Certain issues could be raised as the possible reasons for the preponderance of substandard literature in English textbooks in the. Senior Basic Education level.

The desire to 'Africanize' literary works in order to depict the socio-cultural background of the target readers is one of the reasons for such aberration. To the proponents of African literature like Chinweizu, Onwuchekwa and Ihechukwu, the cultural and national consciousness expressed in the work, whether through the author's voice or through the characters and their consciousness, habits, comportment and diction is one of the important criteria for determining African literature. (14) However, the above criterion does not permit 
the language of a literary text to be ungrammatical or altered in such a manner that it lacks international intelligibility.

Achebe warns that:

... [Though] the price a world language must be prepared to pay is submission to many different kind of use, the African writer should aim to use English in a way that brings out his message best without altering the the language to the extent that its value as a medium of international exchange will be lost (Nnaemeka 281).

The economic difficulty in Nigeria is another major contributor to the problem. Some of the writers are under economic urgency and churn out anything overnight in the name of literature textbooks. To such writers, what matters is the money they make from the sales of the books. They tend to ignore the fact that what qualifies a piece of writing as literature is its literariness achieved through its language and metaphor. The education authorities who recommend the substandard texts either collect bribe from the quasi-authors or are not competent to assess the grammatical level of the textbooks.

In junior secondary schools, didacticism is the basic concern in the choice of literature textbooks for students. The quality of the author's diction is sacrificed at the altar of moral lessons behind the texts. To some of the authors, a text is of good quality if it dwells on social realities; the grammatical level of the language of the text is inconsequential.

A good number of the authors are not English language experts and have not acquired the basic competence for writing. We acknowledge the fact that artistic writing is basically a talent but the grammar of a language must be mastered thoroughly before one can use it with some degree 
of accuracy and confidence. A lucid and convincing piece of writing as a matter of necessity must be grammatical for complete acceptability of such writing as a standard form.,

\section{The Concept of Error:}

The word, error ('errare' in latin), is defined in the Webster's New International Dictionary ofEnglish Language as 'departure from that which is right or correct' (1869). In relation to language study, Corder defines errors as breaches of code of language (76). He argues that errors are deviant structures or unacceptable utterances, which are signs of 'imperfect knowledge' of the linguistic code. He buttresses the fact that errors are committed by those who are not grounded in the structure of a language (Corder 76).Headbloom quoted in Ubahakwe (30) believes that linguistics errors are systematic deviations from the target language by non-native speakers. Ellis (32) shares Headblooms opinion and adds that these errors are committed out of socio-linguistic and socio-cultural factors.

Headblooms and Ellis' argument stresses that errors are exclusive to second or foreign language learners. This implies that native speakers of a language are immune to errors in their languages. Adejare, however, counters this view and avers that 'error is a universal feature of usage and that mother tongue users of a language are also error prone' (58).

Richards quoted in Aiyewumi (4) adds that a linguistic error is not just the outcome of carelessness or unforgettfulness, it is characterized by systematic deviancy. Errors might happen from time to time until the second language learner internalizes the language entirely.

Language errors could simultaneously be diagnostic and prognostic. Diagnostic in the sense that it can tell the learner's level of language acquisition and prognostic in the sense that it can tell a course organizer to re-arrange language 
learning material on the basis of the learner's current problems. A learner's error therefore exhibits his incompetence in a particular aspect of language. Hence, errors are facilitative rather than inhibitory in language learning process.

Errors could be interlingual or intralingual in nature. Interlingual errors are caused by analogy with the native language while intralingual errors imply generalization or faulty application of rules and conditions (Ubahakwe 32).

Errors are different from mistakes. Mistakes could be caused by slip of tongue, oversight in writing, distractions and so on. Mistakes could easily be corrected by the person who made them, but a person who has committed an error is incapable of correcting it unless he is taught the correct form. (Ubahakwe 32).

Errors are deviant structures which should not be ignored in language learning. Erroneous expressions mar the beauty of a piece of writing or speech. It corrupts the language acquired by young learners of a target language. Efforts should be geared towards the elimination of errors in language learning process.

\section{Methodology}

The data for the study is drawn from three textbooks - two prose works and one drama text. The texts are already recommended for Basic 7-9 students. A text is selected from each class.

The errors collected from the texts are collated and classified, based on the following types: syntactic, concord and morphological errors. Each text is analyzed separately. The expressions that mar the sentences are underlined while the corrected versions are enclosed in quotation marks.

In the analysis of the drama text, the Arabic numerals that accompany any of the characters indicate the character's 
first, second, third or fourth speech on a particular page.

\section{Data Presentation And Analysis}

Wishful Bliss - (100 pages) by Chinyere Ilechukwu

\section{Syntactic Errors:}

1. Pg. 2 line 29_...to very interesting places during this long vacation. - "during" and "this" cannot co-occur in a sentence. One will suffice.

2. $\quad \operatorname{Pg} 9$ line $19 \ldots \ldots$... and pluck plenty of pears to bring for my classmates. - . The corrected version should be "...and pluck plenty of pears for my classmates".

3. Pg 10 line 19_...you have not finished washing the clothes since. - the meaning of the underlined expression is vague - "you started since morning" isa better expression.

4. $\quad \operatorname{Pg} 12$ line 3 - of all possibilities that might keep Dike........omission of the definite article, "the" before possibilities - "all the possibilities".

5. $\quad \mathrm{Pg} 15$ lines $11,12 \ldots$ _...we shall return to Atu in the evening tomorrow. The underlined expression is wrong. The correct version is "tomorrow evening".

6. $\mathrm{Pg} 15$ line 16_...she had a sharp resemblance with her husband. 'Resemblance' collocates with "to" and not "with" _ "resemblance to"

7. Pg 15 lines 35-36_..."Mama, do you stay so late in the farm?" I don't stay as long" - incomplete statement. "...as long as I did today"

8. $\quad$ Pg 17 line 14_...a letter of commendation from head office - omission of an article - "from the head office"

9. $\quad \mathrm{Pg} 17$ line 15_...it may be followed up with 
promotion or an equivalent. " - "a" should precede promotion, “its" should replace 'an'

10. $\mathrm{Pg} 18$ line 12 - this your change of location...(another case of transliteration)"this and "your" should not co-occur. One will suffice.

11. $\mathrm{Pg} 18$ lines 25,26_...she is growing like agricultural fowl - an indefinite article must precede the underlined expression, "agricultural fowl". an "agricultural fowl".

12. $\mathrm{Pg} 18$ line 27_...thank your husband for the wine he sent 'sent' a transitive verb has been used intransitively.

13. Pg 25 lines 16,17, 18 - the bulk of the cattle meat (transliteratin) consumed in the Southern part of the country are bred up North. -The phrasal verb "bred up" is wrong. "bred in the north" is the correct expression.

14. $\mathrm{Pg} 27$ lines 2 and 3_...Uzoma wrote the application which Dike helped her draft - Helped is obligatorily used with a full infinitive, not with a bare infinitive - "helped her to draft"

15. Pg 30 line 1 - In the next week,Uzoma wrote two other applications. The underlined adverbial phrase is wrong._" the following week" is preferable.

16. Pg 41 lines 21-22_...not much patients were around - "much" collocates with uncountable nouns and not with countable nouns - "many patients"

17. Pg 41 line 21_...some it was who sere flashily turned out so that they could impress the interviewers. (Clumsy expression). Recast as "some came in gorgeous clothes in order to impress 
the interviewers".

18. $\mathrm{Pg} 52$ lines 24-25 - when the formality of greeting was over, Uzoma led her mother inside her bedroom - "into".

19. $\operatorname{Pg} 58$ line 7 - following her behind was Ndidi. Wrong placement of a preposition. - "following behind her was Ndidi".

20. Pg 62 line 29 - Rhoda took the ingredients_into the kitchen and removed the fruit into a bowel. transliteration error_..."to the kitchen and put the fruits in a bowl" is the correct expression

21. Pg 79 line 9_...that he would still travel North the next day - omission of a preposition, "to" and a definite article. "to the North"

22. $P g 79$ lines 31-32 - Dike was packed and ready to go home. (Clumsy) - "Dike had parked and was ready to go home"

23. $\mathrm{Pg} 88$ lines $13-14$ - it is after three - "it is past three" (in relation to time)

24. Pg 88 line 14_....it is time we get going - "it is time we got going"

25. $\mathrm{Pg} 100$ line 18 - she also wrote an application to head office - omission of an article. "the head office"

\section{Concord Errors:}

26. Pg 2 line 25_...Mama, I told Ekene that I will come - "would" and not "will".(Concord incongruity between "told" and "will").

27. Pg 13 lines 20-21 - Our teacher often say....... (singular subject + plural verb) - "says"

28. Pg 18 lines 18-19_...there is Chidi and Nweke to go to. (singular verb + plural subject) - "are"

29. Pg 32 lines 22-23 - the petty trading........no 
longer sustain me (singular subject + plural verb)

- "sustains"

30. $\mathrm{Pg} 45$ lines 36-37_...in a manner that suggest intimate friendship. (singular subject + plural verb) - "suggests".

31. Pg 46 line 10_...Rhoda have stolen your heart. (singular subject + plural verb) - "has".

32. Pg 52 lines 2-3. He presents them......... (singular subject + plural verb) "presents".

33. Pg 85 line 26_...guess what I got yesterday, I

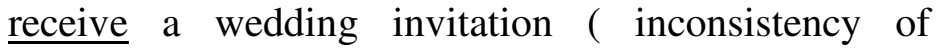
tense) "received".

\section{Morphological Error}

34. $\quad \operatorname{Pg} 2$ line $21 \ldots$ _...females to cover their hairs always. "hair".

35. Pg 30 line 2 _...at half past eight or there about. "thereabouts" is a word and it is often pluralized.

36. Pg 46 Ojadike $^{3}$ : lines 15, 16, 17 - where have the people of Mbara kingdom done wrong that.... "Gone 36. Pg 85 line 12 - this line of gossips formed the main topic - "gossip"

37. Pg 92 line 36 - she went to the market to buy some inputs. "items"

\section{The Decree of The God's (89 pgs) (Drama)by EmmanuelChukwudi}

\section{Act I Scene I. SYNTACTIC ERRORS:}

1. $\mathrm{Pg} 1$ line $5 \ldots$...Egboka ${ }^{1} \ldots . .$. someone to use mirror...the ornament in his wrist - omission of an indefinite article before mirror, wrong choice of preposition - "the mirror" "on his wrist" 
2. $\quad$ Pg 3 line 7 Egboka $^{1}$ _...set our land free from curse. Omission of an article "a curse".

3. Pg 4 line 8 Ezemmuo $^{1}$ : _....have decided to smile to you once again. Wrong choice of a preposition. "Smile on" to indicate good luck.

\section{Act I Scene 2}

4. $\quad$ Pg 6 lines 3, 4, 5 Adaugo ${ }^{1}$ :...if I say that I missed you..... I will not be saying the real fact._transliteration error. "It is an understatement" is the correct expression.

5. Pg 11 Adaugo ${ }^{\text {: }}$ lines 1,2 - why did they kill her? Has she a witch? - Wrong choice of a verb "is she a witch?"

\section{Act 2, Scene 2}

6. $\quad \operatorname{Pg} 30$. Adaugo ${ }^{1}$ : lines 3, 2 - you are fond of jumping queue - omission of an article. "The queue".

7. $\quad P g$ 39, 40. Adaugo ${ }^{1}$ : lines 2 and 3 - you risked your life to the evil forest - wrong preposition "at"

8. $\quad \operatorname{Pg} 42$ Emenike $^{1}$ : line 26 - I'm still begging that the gods will have pity us....omission of a preposition. "Pity on us".

9. $\mathrm{Pg} 47$ Ojadike $^{1}$ : line 2 Obiodu! Where is him? "he".

11. $\operatorname{Pg} 48 \mathrm{Nduka}^{1}$ : line $1 \ldots \ldots$ we are here for solution what to do. Omission of an article; clumsy expression... solution to the problem".

12. Pg 55. Emenike ${ }^{1}$ : lines 16, 17, in couple of days. "in a couple of days"

\section{Act 3, Scene 2}

13. Pg $60 \mathrm{Nkechi}^{2}$ line 1 - Akataopiri has great power omission of an article. "a great power". 105 


\section{Act 3, Scene 3}

14. Pg 65 -Commentary: line $8-$ He ties red wrapper. an indefinite article should precede "red"_ "a red wrapper" .

15. $\operatorname{Pg} 70,71$ - Emenike ${ }^{1}$ : lines 3..... I would make sacrifice to them.... Omission of an article "A sacrifice".

\section{Act 4, Scene 2}

16. Pg 84 Emenike $^{1}$ : lines 6,7 Mgbeke at the door with tears - "In tears" or "with tears in her eyes".

\section{Concord Errors:}

17. Pg 2, 3 Egboka $^{2}$ : lines 18, 19, 20, 21... We sent sons, men and youths alike,........any person that succeeded......will be made the king. Inconsistency in tense usage. "Would" is preferable.

\section{Act I, Scene II}

18. $\operatorname{Pg} 8$ Emenike $^{1}$ : lines 3, $4-\mathrm{He}$ pulls her up and make her sit beside him. "Makes".( incongruity between the subject and the verb of the second clause).

\section{Act 2, Scene I}

19 .Pg 23 Nneoma: lines 8, 9 -crying can never solve a problem, instead it worsen... it "worsens". ( the subject does not agree with the verb).

\section{Act 3, Scene I}

20. $\operatorname{Pg} 44 \mathrm{Agada}^{3}$ : lines 1,2 the youth are here in the palace... "The youths are..."

21. Pgs. 53-54 Anyika ${ }^{3}$ : lines 18, 19......our youth 
are tired of digging graves. "Our youths are...."

22. Pg 56 Ojadike $^{2}:$ He has promised us peace as he usually promise. "As he usually does".

\section{Act 3, Scene 3}

23. Pg 67 Akataopiri ${ }^{1}$ : lines 2, 3, 4. He raises head and look at Igwe - "looks"

\section{Morphological Errors:}

Act 1, Scene 2

24. $\operatorname{Pg} 12,13$ Emenike $^{2}$ : lines 15, 16 life was quickly walking away from him. "fading away".

25. Pg 64 Agboma : line 5 _ she is shock "shocked"

\section{Act 3, Scene 1}

26. Pg 46 Ojadike $^{3}$ : lines 15, 16, 17 where have the people of Mbara kingdom done wrong..... "gone wrong".

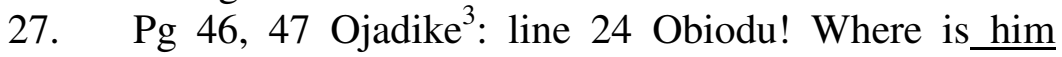
"he".

28. Pg 53 Ojadike ${ }^{1}$ : line 1 - you are saying that fact. "Stating the fact" or "saying the truth.

29. Pg 54 Anyika $^{3}$ : lines 1,2 - instead dreadful diseases and death continue to romance us...malapropism_"torment".

30. Pg 54 Ojadike ${ }^{1}$ : lines 6, 7_We the youths have said our minds and we stand onit_. The correction for the underlined words are "spoken" and "by" respectively.

31. $\mathrm{Pg} 55$ Emenike : lines 16, 17 In couple of days...(omission of an indefinite article before "couple")_ in a couple of days .

32. $\operatorname{Pg} 61 \mathrm{Nkechi}^{1}$ : lines 2, 3, 4 - they run towards the 
direction from which the cry is coming - "from where they hear the cry".

33. Pg 64 Agboma $^{3}$ : line $5-$ she is shock "shocked"

34. Pg 76 Egoka $^{1}$ : lines $2,3,4,5 \ldots$ even if we can go starve to fulfill... _ "starving".

\section{That's My Girl (102 pages) (prose) by Nneka Anekwe Syntactic Errors:}

35. Pg 7 lines 18, 19 - every attention would be to her.... "Every attention would be on her".

36. $\operatorname{Pg} 7$ lines $19,20 \ldots$. I was happy because she was my sister and could play with her - omission of the pronoun "I" ...And I could play with her".

37. Pg 8 line $21 \ldots .$. Check on baby, Mmesoma "check on the baby...."

38. Pg 16 lines 15, 19, 20, 21 - As I rushed to find out what the matter was, I slipped on stepping on the water I split on the floor then fell down landing with the back of my head. (Clumsy because of superfluous use of the preposition, "on" . Also a transliteration of Igbo utterance as a result of interference) "As I rushed out to discover what had happened, I stepped on the water that I spilt on the floor, fell down, and hit the back of my head against the floor".

39. $P g 16$ lines 24, 25, pg 17 line $1 \ldots \ldots$ the bleeding stopped..... With the help of pressure I exerted on it. "the pressure".

40. Pg 18 lines 6, 7 - it was during her visit that I knew a lot of folktales "learnt".

41. Pg 20 lines 16, 17, 18 _ When am old they sell me off.... "When I am old".

42. Pg 23 line 16 - when dog left in that high speed.... 
"the dog".

43. $\operatorname{Pg} 23$ line 19 - having ran for a long distance..... "For" is otiose in the sentence "having ran a long distance".

44. $\operatorname{Pg} 24$ line 13, 14.... 'Slow and steady' win the race. "slow and steady wins the race".

45. $\operatorname{Pg} 27$ line 18, 19 - fully awake, I laid motionless on my bed, looking through the window to the rising sun. (dangling modifier) "....I lay motionless on my bed and looked at the rising sun through the window".

46. Pg 28 line 19.... haveyour bath.... "have a bath"

47. Pg 29 line 17.... Mummy, do you mean am a gift (Omission of a pronoun) "...Mummy do you mean I am a gift?".

48. $\quad \operatorname{Pg} 30$ line 20 - I let go her hand. “.....go of her hand"

49. Pg 40 line $18 \ldots . .$. She stopped crying but still on my arms. "though she was still in my arms".

50. Pg 44 lines 12, 13, 14 - Mummy and Mrs. Okoye were inside the compound within minutes and immediately out of the car MrsOkoye shouted (Clumsy and ambiguous) "Mummy and Mrs. Okoye were inside the compound within few minutes and Mrs. Okoye shouted as soon as she came out of the car".

51. $\quad \mathrm{Pg} 45$ line $14 \ldots$ Some people because of their social status look down on the others. (- "on others" (the) is otiose).

52. Pg 70 lines 1, 2. I prayed you will not get married, yet because you were sad when your mummy came" ('yet' is otiose) "......you will not get married because...."

53. Pg 72 lines 17, 18 - the inclusion of Amaka was an 
uphill task, because though Mrs. Okoye was in full support of the drama - (the meaning of the sentence is vague. The underlined words cannot co-occur in a sentence)_ "the inclusion of Amaka was an uphill task despite the fact that Mrs. Okoye was in full support of the drama".

\section{Concord Errors:}

54. $\mathrm{Pg} 12$ lines 16, 17....Nwakaego gathers firewood and sell. ("Sell" is a transitive verb and must go with a complement; singular subject selects a singular verb) "Nwakaego gathers firewood and sells at the market".

55. $\mathrm{Pg} 12$ lines 19, 20...where she grows vegetables and sell "sells".

56. $\operatorname{Pg} 15$ line 15,16 - the only thing she liked was songs. "The things she liked were songs".

57. $\mathrm{Pg} 12$ line 5 - there was some minutes silence "there were some minutessilence".

58. $\operatorname{Pg} 21$ lines 8,10 - he who does not know where the rain started beating him will not know where it stopped. (Inconsistency in tense usage) "did", started, would, stopped".

59. $\operatorname{Pg} 22$ lines $11,12 \ldots$ The Lion roared bitterly knowing that he hasbeen tricked._"had". (inconsistencyin tense usage).

60. Pg 36 line 11 - He always call anyway. "calls". (there is no agreement between the subject and the verb).

61. Pg 52 line Do you know how much it cost me... "costs" (subject-verb disagreement)

\section{Morphological Errors}

62. $\quad \mathrm{Pg} 12$ line 6- I was busy rinsing the cutleries 
"cutlery"

63. Pg 54 line $1-$ she is one of the executive "executives".

64 . Pg 62 line 11, 12...... But as search party was sent to look for me "a".

65. $\mathrm{Pg} 18$ lines 6,17 - It was during her visit that I knew a lot of folktale. "Learnt" "Folktales"

\begin{tabular}{|l|l|c|}
\hline $\begin{array}{l}\text { Title of the } \\
\text { book }\end{array}$ & Types of errors & $\begin{array}{l}\text { Frequency of } \\
\text { occurrence }\end{array}$ \\
\hline A Wishful & Syntactic errors & 25 \\
Bliss (prose) & Concord errors & 8 \\
& Morphological errors & 4 \\
\hline The Decree & Syntactic errors & 16 \\
of the gods & Concord errors & 6 \\
(drama) & Morphological errors & 11 \\
\hline That's My & Syntactic errors & 19 \\
Girl (prose) & Concord errors & 8 \\
& Morphological errors & 4 \\
\hline
\end{tabular}

The errors found in the textbooks are classified in the table below:

The table below shows the total number of errors in the selected texts :

\begin{tabular}{|l|l|}
\hline Errors & Frequency \\
\hline Syntactic & 60 \\
\hline Concord & 22 \\
\hline Morphological & 19 \\
\hline Total & $\mathbf{1 0 1}$ \\
\hline
\end{tabular}




\section{Discussion of Findings}

The above table revealed that the three analyzed literature textbooks are replete with different grammatical errors. Syntactic errors top the list. There are also preponderance of concord and morphological errors. Syntactic errors are more interlingual than intralingual. A lot of transliteration from Igbo language to English language are discovered in the corpus. These are erroneous expressions like "in the evening tomorrow", some it were flashily turn out so that they could impress the interviewers "following her behind" and such other aberrations.

Concord incongruity and morphological errors mar the beauty of any piece of writing rendered in the English Language. Concord and morphological errors are more of interlingual than intralingual. Such errors occur because the writers have not internalized the rules guiding the agreement of words in sentences as well as the morphological rules of the language. Some of the errors could also be caused by over generalization of rules, learning by analogy, carelessness and thoughtlessness. One should also not rule out the fact that some of these errors are typographical errors. This calls for carefulness on part of the writers and publishers.

The profile of the authors reveals that though they are university graduates, none of them studied English, hence they are not English language experts. Perhaps they inadequately contributed a great deal to the poor quality of their works. None of the textbooks is literary in every sense of the word.

\section{Conclusion}

The above findings are clear evidence that literature textbooks analyzed in this work are unsuitable for students in Senior Basic Education level because of the poor quality of the language of the textbooks. The language of such textbooks would inhibit instead of facilitate the students learning of 
English Language.

The ungrammaticality of some of the expressions in the books would corrupt the good English acquired by their readers and when such errors fossilize in the learners linguistics repertoire, they will be extremely difficult to correct.

To avoid making wrong selection of literature textbooks for students, all the stakeholders in the students' education should be wary of the books they recommend for them. The stakeholders include parents, government, education policy makers, principals and teachers.

All in all, the position occupied by the English language in Nigeria and the pivotal role it plays in every facet of the life of the country can never be underplayed. To speak and write good English is rooted on the ability of the user to avoid derailment from the norms of the language. Nothing should be taken for granted. Every effort must be geared towards the promotion of standard English.

\section{Recommendations}

Exposure to good reading materials makes learners of English as a second language acquire proficiency the language. To achieve this, government must not only ensure that literature textbooks written by language experts are recommended in schools, they should equally discourage nonEnglish language graduate teachers from teaching literature in English.

Talented writers who are non-English languages experts should employ the services of competent proofreaders before the final publication of their works. Publishing houses should equally employ English language experts as their editors and such editors ought to be thorough and painstaking in performing their duties. Literature books must also be 
reviewed critically by the relevant authorities before are recommended for students.

Finally, English language and Literature in English teachers as well as writers of students' literature textbooks must be encouraged to attend relevant seminars and workshops. They should also be adequately motivated and remunerated. These will invariably bring the errors committed by writers to the barest minimum.

Edith Ifeyinwa Obi \& Odochi Silver Akujobi ifyedith20@yahoo.com odochiakujobi@yahoo.com Department of English Language and Literature NnamdiAzikiwe University Awka 


\section{Works Cited}

Aiyewumi, Mabel, Ruth Agamah and Stephen Oloruike Remedial English for Professional Students. Kaduna: Lantern, 2011. Print.

Akwanya, A. N. English Language in Nigeria: In Search of Enabling Principle. Nsukka: University of Nigeria Press, 2007. Print.

Anaekwe, Nneka. That's my Girl. Awka: Laity Press, 2012. Print.

Azikiwe, Uche. Language Teaching and Learning. Onitsha: Africana First, 1998. Print.

Chinweizu, Onwuchekwa Jemie and Madubuike, Ihechukwu. Toward the Decolonization of African Literature: African Fiction and poetry and their Critics: vol.1 Enugu: Fourth Dimension, 1980. Print

Corder, S. P. Error Analysis and Interlanguages. London Oxford, 1969. Print.

Ellis R. Understanding Second Language Acquisition. Oxford: Pergamon Institute of English, 1985. Print.

Eyisi, Joy. "The Teaching of English in Nigeria Problem, Effects and Remedies." A paper presented at first International Conference on Education, Ebonyi State University, Abakiliki, 2005. Print.

Ezeaku, Afamefuna. "Critical Appreciation of Literature" in Ezeaku Afamefuna, Ogbazi, Ifeyinwa and Ifechelobi, Jane. (eds.) English for Academic Competence. Awka: Fab Anieh Publishers, 2012. Print.

Federal Republic of Nigeria .National Policy on Education. Revised Ed. Lagos. Federal Ministry of Information, 2004. Print.

Headbloom, Alan, "Error Analysis and Theoritical Considerations in Second Language Learning" in Ebo Ubahakwe (Ed) The Teaching of English Studies: Reading for Colleges and Universities. Ibadan: University Press, 1979. Print. 
Ibekwe , Emmanuel Chukwudi. The Decree of The gods. Awka: Diamond Pen Publishers, 2012. Print. Ifechelobi, Jane Nkechi. " Learner Autonomy and the Second Language Learner" in AJELLS: Awka Journal of English Language and Literary Studies. Awka: Vol.4, No. 1. 2013. 56-66. Print.

Ilechukwu, Chinyere. Wishful Bliss. Awka: Fourth Dimension, 2005. Print.

John, Joseph. " Language Versus Literature in University English Departments". In Forum, xxiv (4), Ibadan: 1986. 18-22. Print.

Leech, G.N. Semantics: The Study of Meaning. London : Penguin Books, 1981. Print.

Nnaemeka, Obioma. "Chinua Achebe: Women, Language and Border (Lines) Lands." In Edith Ihekweazu (Ed.) Eagle on Iroko: Selected Papers From the Chinua Achebe International Symposium 1990. Ibadan: Heinemann, 1996. Print.

Nnamdi - Eruchalu, Geraldine. "The Place of Literature in Promoting Proficiency in English" Ezeaku, Afamefuna, Ogbazi, Ifeyinwa and Ifechelobi, Jane (Eds) English for Academic Competence. Awka: Fab Anieh Publishers, 2013. Print.

Uzoho, Chioma. "Bridging the gap between Language and Literature: The Case for French Literature in the Nigerian Situation". In Unizik Journal of Arts and Humanities (2013). Vol. IX. Pg 58-65. Print.

WAEC. The West African School Certificate Examination Chief Examiner's Reports. Nigeria, May/June 2009. Print.

. May/June 2010. Print.

-

Webster, N. The New Webster's Dictionary. New York: Lexicon Publication, 1987. 